\title{
Ammonite faunas and the 'standard zones' of the Cenomanian to Maastrichtian Stages in their type areas, with some proposals for the definition of the stage boundaries by ammonites.
}

\author{
WILLIAM JAMES KENNEDY
}

\begin{abstract}
Kennedy, W. J.: Ammonite faunas and the 'standard zones' of the Cenomanian to Maastrichtian Stages in their type areas, with some proposals for the definition of the stage boundaries by ammonites. Bull. geol. Soc. Denmark, vol. 33, pp. 147-161, Copenhagen, September, 11th, 1984

https://doi.org/10.37570/bgsd-1984-33-13

The 'standard zones' of the Cenomanian to Maastrichtian Stages as applied to the western European region are critically evaluated, and their development within the type areas of these stages is reviewed. Proposals for defining the bases of the Upper Cretaceous stages worldwide using ammonites are: Cenomanian: appearance of Hypoturrilites Dubourdieu, 1953 or Neostlingoceras Klinger \& Kennedy, 1978; Turonian: appearance of Pseudaspidoceras flexuosum Powell, 1963; Coniacian: appearance of Forresteria (Harleites) petrocoriensis (Coquand, 1859); Santonian: appearance of Texanites species; Cam-panian: appearance of either Placenticeras bidorsatum (Roemer, 1841), Submortoniceras Spath, 1921, or on the basis of evolutionary changes within the Scaphites hippocrepis (De Kay, 1827) lineage; Maastrich-tian: appearance of Pachydiscus neubergicus (Von Hauer, 1858).
\end{abstract}

W. J. Kennedy, Geological Collections, University Museum, Oxford. OX1 3PW, February 3rd, 1984.

\section{Introduction}

The type areas of the Cenomanian, Turonian, Coniacian, Santonian, Campanian and Maastrichtian Stages provide, to varying degrees, a series of localities where the visitor can see for himself what d'Orbigny, Coquand and Dumont respectively regarded as typical fossils and lithologies of each of these six divisions of the Upper Cretaceous. As an extensive literature demonstrates, they are none of them very suitable for defining the relevant stage boundaries, for with the exception of the Campanian, there are sedimentary breaks around the upper and lower limits of all these stages in their type areas. In spite of this, they remain very suitable reference points for the Cretaceous stratigrapher, because each type area shows a variety of facies and faunas in what are physically and politically readily accessible parts of the world.

In this review I outline the 'standard zones' of the Upper Cretaceous stages that are in current usage, discuss their validity and development in the type areas, and propose what are, in am- monite terms, likely to be potential marker points for defining the bases of stages.

My own view is that stages are packages of zones, and that it is the base of a zone that is the most sensible way to define the base of a stage.

Discussions at the Copenhagen symposium revolved around appearances of individual taxa on species or genus level, however, and in deference to this my suggestions are made to conform with such an approach.

I have attempted to define boundaries based on ammonites that fall within the breaks at the base of the Upper Cretaceous stages in their type areas (the Campanian excepted, of course). Some of the proposals are unfamiliar, but experience has shown that new, finer biostratigraphic subdivisions, if they are real rather than paper stratigraphy, are often rapidly and widely recognised following their first description. Thus the Neocardioceras juddii Zone, introduced by Wright \& Kennedy in 1981 , was originally documented from southern England, with 3 other records from France and the Germanies. It is now widely recognised in the U.S. Western Interior, 


\begin{tabular}{|c|c|c|}
\hline SUBSTAGE & STANDARD ZONES & VARIANTS/SUBZONES \\
\hline $\begin{array}{c}\text { LOWER } \\
\text { TURONIAN } \\
\text { (part) }\end{array}$ & Watinoceras coloradoense & \multirow{2}{*}{$\begin{array}{l}------------- \\
\text { Horizon A }\end{array}$} \\
\hline \multirow{3}{*}{$\begin{array}{c}\text { UPPER } \\
\text { CENOMANIAN }\end{array}$} & Neocardioceras juddii & \\
\hline & Metoicoceras geslinianum & $\begin{array}{l}\text { Unnamed Nigericeras }+ \\
\text { Thomasites fauna }\end{array}$ \\
\hline & Calycoceras guerangeri & $\begin{array}{l}\text { Also called } E \text {. pentagonum or } \\
C \text {. naviculare Zone; both range above }\end{array}$ \\
\hline \multirow{3}{*}{$\begin{array}{c}\text { MIDDLE } \\
\text { CENOMANIAN }\end{array}$} & Acanthoceras jukesbrownei & \\
\hline & \multirow{2}{*}{ Acanthoceras rhotomagense } & Turrilites acutus \\
\hline & & Turrilites costatus \\
\hline \multirow{3}{*}{$\begin{array}{c}\text { LOWER } \\
\text { CENOMANIAN }\end{array}$} & Mantelliceras dixoni & $\begin{array}{l}\text { Sometimes called } M \text {. orbignyi } \\
\text { Zone (a synonym of dixoni) }\end{array}$ \\
\hline & \multirow{2}{*}{ Mantelliceras mantelli } & Mantelliceras saxbii \\
\hline & & Neostlingoceras carcitanense \\
\hline $\begin{array}{c}\text { UPPER } \\
\text { ALBIAN } \\
\text { (part) }\end{array}$ & Stoliczkaia dispar & Stoliczkaia dispar \\
\hline
\end{tabular}

Table 1. Cenomanian ammonite zones.

and can be correlated with the portuguese, Middle East and West African sequences via common elements of both Boreal and Tethyan aspect.

\section{Cenomanian}

When Alcide d'Orbigny began to divide up the Cretaceous system into stages, he at first recognised only two in what is now known as the Upper Cretaceous: Turonien and Sénonien (Palé- ontologie Française, Terrains Crétacés, II Gastéropodes, pp. 403-406). With respect to the Turonian, his words are: "je propose de désigner à l'avenir l'étage qui m'occupe sous le nom de terrain TURONIEN, de la Ville de Tours (Turones) ou de la Touraine (Turonia), situées sur ces terrains" (d'Orbigny 1843, p. 405), defining the Turonian as equivalent to the Craie Chloritée, Craie tuffeau, Glauconie crayeuse, Grès Vert Supérieur etc., and taking the name from Touraine (Roman Turonia). Five years later, he realized 
that two distinct ammonite and rudist faunas were present, and he restricted the term Turonien to beds corresponding to his third zone of rudists, yielding "Ammonites lewesiensis, peramplus, Vielbancii, Woolgari, Fleuriausianus, Deverianus etc.", "le plus beau type côtier étant très prononcé dans toute la Touraine, et nous donnerons à la partie inférieure le nom d'étage Cénomanien, le Mans (Cenomanum), en montrant à la fois le type sous-marin" (d'Orbigny, 1848, p. 270).

In the second volume of the Prodrome d'Orbigny (1850) listed 46 ammonites as being characteristic of the Cenomanian, of which 10 were specifically cited from Sarthe, in which Le Mans lies. Localities mentioned are Saint-Calais, La Flèche, Cérans, Ecommoy, Grand Luce, Coudrecieux, Vibraye, Lamnay and La Ferté-Bernard.

A few ammonites from the Cenomanian of Sarthe were described by Guéranger (1867) in his Album Paléontologique du département de La Sarthe, one of the earliest publications with photographs of fossils, and the stratigraphy was investigated in particular by Guillier (1886). The ammonites were then neglected for almost 100 years, until Hancock (1960) listed all the stratigraphically localized Cenomanian ammonites he was able to trace in the Le Mans and Paris Collections, as well as new material collected by him, a total of 161 specimens. This work forms the basis of all subsequent studies.

Latterly, large collections of new material have been assembled, largely through the efforts of Pierre Juignet and André Lebert, so that more than 3000 individuals, accurately placed in sequence, are now available. These have been the basis of preliminary lists in Juignet (1974, 1977), Juignet et al. $(1973,1978)$ and Kennedy \& Juignet (1973); systematic revision is now in progress (Kennedy \& Juignet 1983, in press).

In spite of recent opinions that the environs of Le Mans are inadequate and unsuitable as a type area (Marks 1967a, b; Thomel 1973, p. 763), it was an excellent choice. The area is one of diverse facies, and faunas of great richness and variety. There is, however, a regional hiatus at the base of the Cenomanian in most of western Europe (although not recognised to date in Sarthe), while fossils are rare in the lowest beds in the type area.

The zonation of the Cenomanian in western
Europe has progressed erratically because of the lack of adequate taxonomic work. Wright, Kennedy \& Hancock (in press) propose a compromise zonation between the work of Hancock (1960), Robaszynski \& Amédro (1980), and Juignet \& Kennedy (1976) that can be applied where fine subdivision of the Lower and Middle Cenomanian is not possible. Combined with the work of Wright \& Kennedy (1981), this leads to parallel zonations with greater and lesser degrees of precision, as shown in table 1. (Note that the carcitanensis and saxbii, costatus and acutus Zones can be treated as subzones of the mantelli and rhotomagense Zones respectively).

The chief difficulty with Cenomanian zonation has been the search for an index species for what has been, successively, the naviculare, pentagonum and guerangeri Zone as a result of the recognition that the range of the index species extended (in the case of the first two) outside the restricted zone named after them.

In Sarthe, the oldest Cretaceous sediments are Upper Albian (Juignet et al. in press). These are overlain by poorly fossiliferous Lower Cenomanian with Mantelliceras, Schloenbachia, Neostlingoceras, Hypoturrilites, Idiohamites and other taxa. Above, the diverse and variable facies of the Sarthe yield good assemblages from all but the juddii Zone, where only one example of the index species is known.

The heteromorph ammonites of the family Turrilitidae provide the best group for defining the base of the Cenomanian, because they have a limited time range but a wide geographic distribution throughout the world and because a continuous phylogenetic series is known from Upper Albian through to Cenomanian. I would propose the appearance of either Hypoturrilites Dubourdieu, 1953 or Neostlingoceras Klinger and Kennedy, 1978 as defining the base of the stage.

A reference section should be designated in the Monts du Mellègue to Pont du Fahs region of Tunisia, an area that is easily accessible with permanent sections with over $90 \%$ exposure. The succession is thick and continuous, ammonites are abundant and include a wide range of taxa, while planktonic microfossils are present and documented. Added to this, the sequence at Djebel Fguira Salah near Pont du Fahs has already been proposed as a Mesogean hypostratotype for the stage (Salaj 1973, 1974; Salaj \& Bellier 1978). 
The base of the range of both Hypoturrilites and Neostlingoceras lies within, and probably at the base of the Hypoturrilites schneegansi Zone of Dubourdieu $(1953,1956)$.

\section{Turonian}

The type area of the Turonian Stage is in Touraine, France, between Saumur (on the Loire) and Montrichard (on the Cher) and was so restricted by d'Orbigny in 1852, following the introduction of the stage by the same author in 1843 and its subsequent limitation in 1848 with the introduction, for the lower part of the sequence, of the étage Cénomanien, as already discussed.

There is now a wealth of literature on the Turonian of western Europe and the ammonite faunas and stratigraphy of the region, the stratotype in particular has been minutely discussed (bibliography in Wright \& Kennedy 1981, Kennedy, Wright \& Hancock 1983, Kennedy et al. 1984 for ammonites; Robaszynski 1982, Alcaydé 1983, Robaszynski et al. 1983 for stratigraphy and other groups).

There is a measure of agreement on the succession of ammonite faunas, but not on the zonal and substage division, as summarised in table 2 . There are a number of relevant comments that must be made on this table:

1. The Cenomanian Turonian boundary corresponds to an important oceanic anoxic event (Schlanger et al. in press, with references) and this markedly affected the sedimentary sequence from the juddii to basal nodosoides Zone.

2. There is widespread condensation and several breaks around the Cenomanian/Turonian boundary in western Europe, so that the sequence is generally thin and the zonal succession locally incomplete.

3. There is an unnamed assemblage between the geslinianum and juddii Zones as noted previously (table 1).

4. The Watinoceras coloradoense Zone is unfortunately named because although Watinoceras is common, the nominate subspecies is absent and the base of the zone is drawn at a lower level than the base of the zone of the same name in the U.S.A.

5. The turoniense, kallesi and ornatissimum
Zones of French workers are best regarded as locally recognisable units only.

6. Kamerunoceras turoniense occurs with Mammites nodosoides (Schlüter, 1871) in the Lower Turonian elsewhere in the world.

The chief discrepancy between French and English workers is the positioning of the Middle Upper Turonian boundary. The argument of Francis Amédro and his co-workers is that de Grossouvre (1901) and Collignon (1960) regarded Romaniceras deverianum as Upper Turonian, and that historical precedent should be followed. This is spurious; de Grossouvre recognised a lower, Saumurien and an upper, Angoumien Substage of the Turonian, the boundary falling in the woollgari Zone of the present account (note that de Grossouvre (1901), in table 37 (p. 830), refers the Tuffeau de Saumur to the Angoumien and the Tuffeau de Bourré upwards to the Salmurien, while Collignon at no point refers to Middle Turonian in the paper cited). It is indeed true that Collignon (1939 p. 96) referred $R$. deverianum to the Angoumien, but he again spoke only of Turonien inférieur and supérieur in that work.

All but one of the 'standard' zones of the Anglo-Saxon (and French) schemes can be recognised in the type area of the Turonian; the coloradoense Zone by a single specimen, the nodosoides Zone by a rather better assemblage and the woollgari Zone by abundant material. The neptuni Zone is not represented within the stratotype, but the index species occurs rarely in the immediate environs, as at Villedieu-le-Château (Loir-et-Cher), only $45 \mathrm{~cm}$ below the base of the Coniacian Craie de Villedieu.

So far as the base of the stage is concerned, Wright \& Kennedy (1981) and Kennedy, Wright \& Hancock (1983) argue, on admittedly thin historic evidence, that the juddii Zone should be taken as Cenomanian, the coloradoense Zone as Turonian, and there is a measure of agreement among ammonite workers on this.

Because of the condensed nature of the successions in Europe, the sequences in Texas and New Mexico appear to be the best described to date for defining the boundary in ammonite terms.

The uppermost Cenomanian to basal Turonian zonal sequence recognised by Cobban (this volume) can be correlated with the European standard as shown in table 3. 


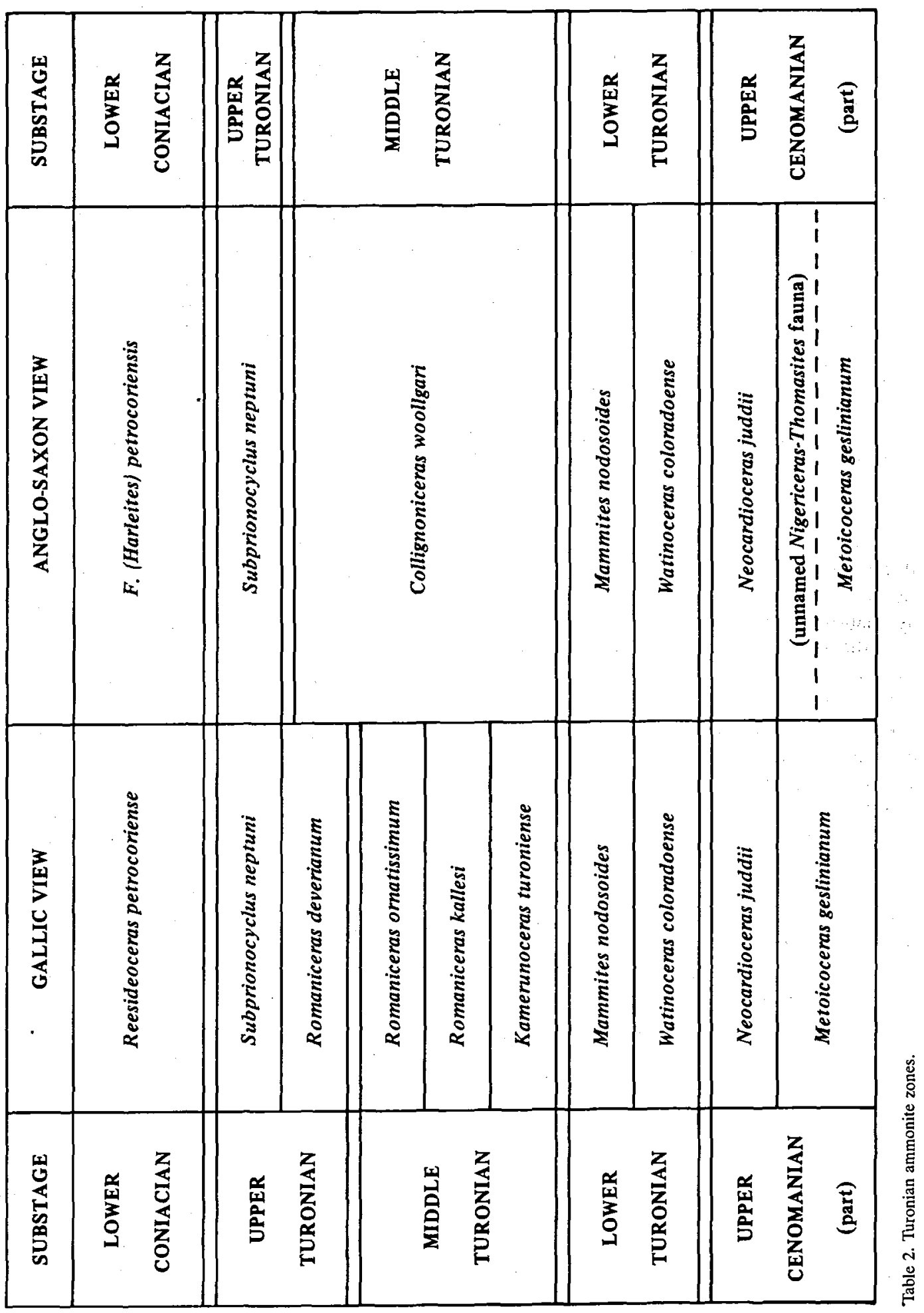




\begin{tabular}{|c|c|}
\hline U.S.A. & EUROPE \\
\hline Mammites nodosoides & Mammites nodosoides \\
\hline Vascoceras birchbyi & \multirow{2}{*}{ Watinoceras coloradoense } \\
\hline Pseudaspidoceras flexuosum & \\
\hline Neocardioceras juddii & Neocardioceras juddii \\
\hline Vascoceras n. sp. & (unnamed Thomasites fauna) \\
\hline Sciponoceras gracile & Metoicoceras geslinianum \\
\hline
\end{tabular}

Table 3. Uppermost Cenomanian-lowermost Turonian Zones.

Watinoceras coloradoense is a birchbyi Zone species in the U.S.A. and is represented in Europe by a subspecies different from the nominate one, occurring with other Watinoceras and Thomasites species.

The base of the flexuosum Zone is here proposed as the base of the Turonian. In its type area the zone yields a mixed fauna of ammonite species (Powell 1963) including some that are shortranging and extend into the Western Interior province, Mexico and California, the Tethyan Vascoceras-dominated faunas of east and north Africa and the European boreal realm, while closely allied, if not conspecific forms also occur in South America, Madagascar, Japan and elsewhere.

The type section of the zone is in Calvert Canyon, west Texas, where there is easy access, $90 \%$ exposure, abundant ammonites and inoceramids (the latter the Mytiloides opalensis of Kauffman, not Böse) while the pelagic facies represented yields planktonic microfossils.

It is arguably unsuitable as a boundary stratotype because the zonal fauna is isolated. Better sections are to be found elsewhere in Texas and New Mexico, where the underlying $j u d d i i$ Zone is ammonitiferous. I defer to Dr. W. A. Cobban to suggest a boundary section.

This boundary corresponds to the appearance of the Mytiloides lineage, which means that the base of the stage can be easily recognised where ammonites are absent.

If this definition is accepted, much of the 'Lower Turonian' of the Tethyan Realm must be reclassified as Upper Cenomanian, as has been recently confirmed by a number of workers, including Hook \& Cobban (1981), who note $\mathrm{Ka}$ merunoceras, Pseudaspidoceras, Vascoceras and Fagesia from the juddii Zone in the U.S., Wright \& Kennedy (1981) who record Thomasites, Nigericeras and Kamerunoceras from below the juddii Zone in England and Lewy et al. (in press) who record the co-occurrence of Metoicoceras geslinianum (d'Orbigny, 1850) and Vascoceras cauvini Chudeau, 1909 in Israel.

\section{Coniacian}

Careful reading of Coquand shows that the grounds of the Seminary at Richemont are the type locality. Fine as this outcrop is, it is singularly useless for collecting fossils. Temporary excavations at this locality in 1982 provided clean sections across the Turonian-Coniacian boundary, and showed Turonian rudistid limestones capped by a hardground and overlain by glauconitic sands of the basal Coniacian piped down into the underlying limestones in Thalassinoides 


\begin{tabular}{|c|c|c|}
\hline Ammonite Zone & Substage & Arnaud Unit \\
\hline Paratexanites serratomarginatus & Upper Coniacian & $\mathrm{L}^{2}$ \\
Gauthiericeras margae & & \\
\hline Peroniceras (Peroniceras) tridorsatum & Middle Coniacian & $\mathbf{L}^{1}$ \\
\hline Forresteria (Harleites) petrocoriensis & Lower Coniacian & $\mathrm{K}$ \\
\hline
\end{tabular}

Table 4. Coniacian Zones.

burrows. This discontinuity surface extends across the Aquitaine basin.

De Grossouvre recognised a 3-fold division of the Coniacian in 1894, but subsequently abandoned this, it would seem as a result of the apparent co-occurrence of species in the basal limestones of the Craie de Villedieu (which we now know to be condensed; fide Jarvis, Gale \& Clayton 1982; Kennedy in press) and the misidentification of ammonites from the Grès Verts de Dieulefit. The 'standard' zones of the Coniacian Stage given by de Grossouvre (1901) are based on successions in Aquitaine, Touraine and Drôme, and are as follows:

\section{Mortoniceras emscheris Zone (above) \\ Barroisiceras haberfellneri Zone (below)}

Neither index species occurs in France. I now recognise the following standard zonation and substages shown in table 4 on the basis of outcrops in Aquitaine plus subsidiary information from Sarthe, Touraine, Dieulefit (Drôme) and Beausset (Var).

A full revision of the more than 40 ammonite species occurring in Aquitaine is given by Kennedy (in press) (see also Kennedy, Wright \& Klinger 1983, and Klinger \& Kennedy 1984). Table 5 summarises the known distribution of Coniacian ammonites in France as a whole.

Ammonites are locally common at the base of the sequence in Aquitaine (essentially Arnaud's Assize K), especially in the Marnes de Montignac and Gourd de l'Arche in the southeastern part of the basin. Most are $F$. (H.) petrocoriensis (Co- quand, 1859), the 'Barroisiceras haberfellneri' of authors from de Grossouvre (1894) to SéronieVivien (1972), and I know of only single speciemens of Scaphites (Scaphites) cf. meslei de Grossouvre, 1894, Metatissotia desmoulinsi (de Grossouvre, 1894) and $M$. nanclasi (de Grossouvre, 1894). The dominance of but one ammonite species raises certain problems; while the base of the Coniacian should undoubtedly be defined, in faunal terms, by the appearance of $F$. (H.) petrocoriensis, it may be that unfavourable environmental conditions in Aquitaine excluded other species and that work elsewhere may show that a more diverse assemblage characterises the petrocoriensis Zone.

The base of the $P$. (P.) tridorsatum Zone is marked by the appearance of diverse Peroniceras (Peroniceras) species. The fauna of this zone is widely recorded in Arnaud's Assize $L^{1}$ in Aquitaine and is marked by $P$. (P.) tridorsatum (Schlüter, 1867) and other Peroniceras (Peroniceras) species with rarer $P$. (Zuluiceras) bajuvaricum (Redtenbacher, 1873). Other ammonites are Onitschoceras? ponsianum (de Grossouvre, 1894), Tongoboryceras sp. nov., Placenticeras fritschi de Grossouvre, 1894, Forresteria (Harleites) nicklesi (de Grossouvre, 1894), Tissotia redtenbacheri (de Grossouvre, 1894), Metatissotia slizewiczi (de Grossouvre, 1894), Metatissotia ewaldi (von Buch, 1847), Metatissotia nodosa (Hyatt, 1904), Tissotioides haplophyllus (Redtenbacher, 1873), Scaphites meslei (de Grossouvre, 1894), Otoscaphites arnaudi (de Grossouvre, 1894) and nodose Baculites. Specimens of Gauthiericeras? boreaui 


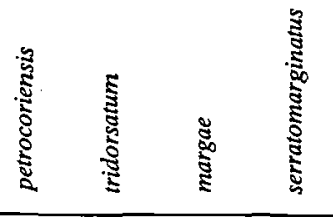

Onitshoceras ? ponsianum (de Grossouvre, 1894)

Tongoboryceras cf. tongoboryense (Collignon, 1952)

Tongoboryceras sp. nov.

Menabonites sp.

Pachydiscoides janeti (de Grossouvre, 1894)

Placenticeras fritschi de Grossouvre, 1894

Placenticeras semiornatum (d'Orbigny, 1850)

Forresteria (Forresteria) alluaudi (Boule, Lemoine and Thévenin, 1907)

Forresteria (Harleites) petrocoriensis (Coquand, 1859).

Forresteria (Harleites) nicklesi (de Grossouvre, 1894).

Peroniceras (Peroniceras) tridorsatum (Schlüter, 1867).

Peroniceras (Peroniceras) lepeei (Fallot, 1885)

Peroniceras (Peroniceras) aff. lepeei (Fallot, 1885).

Peroniceras (Peroniceras) subtricarinatum (d'Orbigny, 1850)

Peroniceras (Peroniceras) westphalicum (Von Strombeck, 1859).

Peroniceras (Peroniceras) dravidicum (Kossmat, 1895)

Peroniceras (Peroniceras) sp.

Peroniceras (Zuluiceras) bajuvaricum (Redtenbacher, 1873)

Peroniceras (Zuluiceras) isamberti (Fallot, 1885)

Peroniceras (Zuluiceras) sp. nov.

Gauthiericeras margae (Schlüter, 1867)

Gauthiericeras nouelianum (d'Orbigny, 1850)

Gauthicericeras ? boreaui (de Grossouvre, 1894)

Protexanites (Protexanites) bourgeoisi (d'Orbigny, 1850)

Protexanites (Protexanites) bontanti (de Grossouvre, 1894)

Paratexanites zeilleri (de Grossouvre, 1894)

Paratexanites serratomarginatus (Redtenbacher, 1873)

Tissotioides (Tissotioides) haplophyllus (Redtenbacher, 1873)

Metatissotia ewaldi (Von Buch, 1878)

Metatissotia slizewiczi (Fallot, 1885)

Metatissotia nodosa Hyatt, 1903

Metatissotia redtenbacheri (de Grossouvre, 1894)

Metatissotia desmoulinsi (de Grossouvre, 1894)

Metatissotia ? nanclasi (de Grossouvre, 1894)

Phlycticrioceras trinodosum (Geinitz, 1850)

Tridenticeras sp.

Eubostrychoceras sp.

Scalarites sp.

Baculites incurvatus Dujardin, 1837

Baculites cf. brevicosta Schlüter, 1876

Scaphites (Scaphites) meslei (de Grossouvre, 1894)

Otoscaphites amaudi (de Grossouvre, 1894)

Table 5. Zonal distribution of ammonite species in the French Coniacian (Aquitaine, Dieulefit and Beausset Basins and Sarthe and Touraine)

(de Grossouvre, 1894) from L in Aquitaine may be from this zone or the succeeding $G$. margae Zone (see below).

The base of the G. margae Zone is marked by the appearance of the index species and $G$. nouelianum (d'Orbigny, 1850). Also present is $G$. boreaui, which perhaps appears first in the underlying $P$. (P.) tridorsatum Zone. Protexanites
(Protexanites) bourgeoisi (d'Orbigny, 1850) first appears in the upper part of the Zone. The margae Zone is represented in Arnaud's Assize L ${ }^{2}$, while it also occurs in the higher parts of the bioclastic limestones of the Coniacian north-east of Saintes (e.g. St. Porchaire).

The base of the Paratexanites serratomarginatus Zone is marked by the appearance of the 
index species. Protexanites (Protexanites) bontan$t i$ (de Grossouvre, 1894) is restricted to the zone, while $P$. $(P$.) bourgeoisi is relatively frequent. This zone is poorly represented in Aquitaine, but characteristic species occur in the higher parts of the dolomitic limestones of the Coniacian near Saujon.

The base of the Coniacian in terms of ammonites is thus the base of the classic 'haberfellneri', rightly petrocoriensis Zone, as is universally accepted. I have proposed elsewhere (Kennedy in press), outcrops at Antignac (CharenteMaritime), the Carrière de Chancelade near Périgueux (Dordogne), the railway cutting at St Cirq, $18 \mathrm{~km}$ WNW of Sarlat-la-Canéda (Dordogne), the roadcut at Aubas (Dordogne), $40 \mathrm{~km}$ ESE of Périgueux, Carlux (Dordogne) and Sauveterrela-Lémace (Lot-et-Garonne) as reference sections for the zone. They are, however, unsuitable as boundary stratotypes because there is a disconformity between Coniacian above and Turonian rudistid limestones and marls below.

A possible solution may be to reinvestigate central European sequences, notably the Priesener Schichten of Czechoslovakia and the North German outcrops in order to link precisely ammonite ranges with those of other groups that may be of more practical value in the field, e.g. Inoceramus species.

\section{Santonian}

At Javrezac, a locality mentioned by Coquand as a type section for both Coniacian and Santonian Stages, the boundary between them is easily drawn at a hardground between glauconitic limestones of the Coniacian below and marls of the Santonian above.

De Grossouvre (1901) recognised a two-fold zonal division:

\section{Placenticeras syrtale Zone (above) \\ Mortoniceras texanum Zone (below)}

Neither species occurs in France, while defining the base of the Santonian in ammonite terms is very difficult in Aquitaine, because the group is rare and most specimens are poorly documented. Madame M. Séronie-Vivien has kindly allowed me to study her precisely localised specimens which, with other records, suggest that the Santonian may correspond to the range zone of Placenticeras polyopsis (Dujardin, 1837), which is the $P$. syrtale of authors (fide Kennedy \& Wright 1983).

De Grossouvre (1894) records Paratexanites ('Mortoniceras') serratomarginatus (Redtenbacher, 1873) from both the Coniacian and Lower Santonian; in 1901 he decided that the Coniacian specimens all belonged to Paratexanites ('Mortoniceras') emscheris (Schlüter, 1876) and that serratomarginatus was exclusively Santonian. He never illustrated Santonian serratomarginatus, and none survive in museum collections that can be attributed to Arnaud's $\mathbf{M}^{1}$. Indeed, later work has shown that serratomarginatus and emscheris are not synonyms and are both from high in the Coniacian (Wiedmann 1979; Kennedy, Klinger \& Summesberger 1981). De Grossouvre (1901) also indicated in a table that Protexanites ('Mortoniceras') bourgeoisi (d'Orbigny, 1850) extended into the lower part of the Santonian but makes no mention of this in the text and no specimens survive from $\mathbf{M}^{\mathrm{l}}$.

Far more widely recorded is Texanites texanus (Roemer, 1852) and this was taken as the index of the lower zone of the Santonian by de Grossouvre. Collignon (1948) correctly interpreted Roemer's species; all European records, he maintained, belonged to two distinct varieties, regarded by subsequent workers as either subspecies of texanus or separate species (I believe them specifically distinct from texanus). Material from $M^{1}$ in Aquitaine (de Grossouvre 1894, p. 80 , pl. 16 , figs. 2,4 ) was referred to the variety gallica Collignon, 1948; the two figured syntypes are actually from $\mathbf{M}^{2}$ at Niel-le-Virouil (CharenteMaritime). The only other specimens seen from Aquitaine are two specimens labelled $A$ mmonites coniaciensis Coquand, 1859 in the École des Mines Collection (now in the Collections of the Université Claude-Bernard, Lyons) ex Boucheron Collection, from La Valette (Charente), a locality referred to Assize $\mathrm{L}^{2}$ by Arnaud, and a specimen in the Sorbonne Collections (now in the Université Pierre et Marie Curie, ex Toucas Collection), from $\mathbf{M}^{1}$, at Les Rentes Cognac. This specimen is a crushed Texanites (Texanites) sp. Boehmoceras occurs in $\mathrm{M}^{2}$ at Nieul-le-Virouli while P. paraplanum (Wiedmann, 1978) and Eu- 
lophoceras occur well above the base of the stage in the autoroute excavations (I thank J. M. Hancock and F. Amédro for allowing me to see these specimens).

There thus seems no possibility of establishing an ammonite zonation of the Santonian in Aquitaine at this time.

The recent work of Bilotte, Calandra \& Collignon (1971) and Bilotte \& Collignon (1983) retains, to a degree, the zonal division of de Grossouvre with a Lower Santonian Texanites texanus Zone, a Middle Santonian Zone of Texanites texanus, Placenticeras syrtale and Eupachydiscus isculensis and an Upper Santonian Zone of Placenticeras syrtale and Eupachydiscus isculensis. The Texanites 'texanus' of the Corbières are actually $T$. gallicus, the Placenticeras 'syrtale' are $P$. polyopsis and $P$. paraplanum.

The ammonite distributions in Aquitaine and the Corbières are in marked disagreement, suggesting that no widely applicable zonation can be proposed on the basis of western European records at this time, pending further systematic and stratigraphic study.

In spite of these problems, there is wide agreement among ammonite workers in areas as far apart as Texas (Young 1963), Japan (Takayanagi \& Matsumoto 1981), southern Africa (Kennedy \& Klinger 1975, Klinger \& Kennedy 1980), Madagascar (Collignon 1966) and the Middle East that the appearance of Texanites (Texanites) is a good indicator of the Santonian, and I would propose the appearance of this genus as the ammonite marker for the base of the stage, but hesitate to suggests a boundary stratotype (Herbert Klinger and I recorded Texanites vanhoepeni Klinger and Kennedy as occurring in our Coniacian V to Santonian I-II in Zululand; this misleading record indicates no more than the presence of that species in the interval mentioned and is not firm evidence for Upper Coniacian Texanites).

\section{Campanian}

The problems surrounding the actual type area(s) of this stage in northern Aquitaine are a matter of some debate, and I defer to the observations of Dr. M. Neumann.
The standard ammonite zonation widely quoted is that based on the work of Schlüter (1871-1876), de Grossouvre $(1894,1901)$ and Haug (1911):

\section{Bostrychoceras polyplocum Zone (youngest) Hoplitoplacenticeras vari Zone Menabites (Delawarella) delawarensis Zone Diplacmoceras bidorsatum Zone (oldest)}

The nomenclature of the index species presents problems enough: Diplacmoceras (correctly $\mathrm{Di}$ placomoceras) is a synonym of Placenticeras (Kennedy \& Wright 1983); European Menabites (Delawarella) delawarensis (Morton, 1830) may not belong to Morton's species (the name campaniensis de Grossouvre, 1894 is available); $\mathrm{Am}$ monites vari Schlüter, 1872 is a junior synonym of Ammonites marroti Coquand, 1859, while no Placenticeras bidorsatum or Bostrychoceras polyplocum have ever been figured from Aquitaine. Add to this the recent work of Blaskiewicz (1980) who defined zones of Didymoceras donezianum and Nostoceras pozaryskii above the polyplocum Zone in the Middle Vistula region of Poland and the observations of Hancock \& Kennedy (1981), who calculated that, if the duration of the Campanian is as great as is generally accepted, then, by comparison with the older stages of the Upper Cretaceous, 20-25 ammonite zones should be recognised!

So far as the type area and elsewhere in Aquitaine are concerned, it is the collections of Arnaud that form the basis of the 'standard' zonal succession, and it was inland railway cuttings that provided much of the key material, for the beautiful coastal sections are relatively barren of ammonites.

I was able to relocate most of the Arnaud/de Grossouvre material in the collections of the Sorbonne, now housed in the Université Pierre et Marie Curie, Paris in 1981-1982; revision is still in progress, but some general observations are possible. The assemblages listed by de Grossouvre are in the correct sequence, but they do not form a zonal succession in the commonly understood sense of that term. Ammonites (other than Baculites) are restricted to narrow horizons, separated by barren chalk, and it is for this reason that the divisions are so coarse. The taxonomy of French Campanian ammonites is in a 


\begin{tabular}{|c|c|c|c|c|c|c|c|c|c|c|c|c|c|c|c|c|}
\hline STAGE & $\mathrm{Ca}$ & $\mathrm{mp}$ & & & & & Maa & str & ich & itia & & & & & & \\
\hline SUBSTAGE & & $\begin{array}{l}\text { per } \\
\text { art) }\end{array}$ & & & & & & & & & & & & & cla & sic \\
\hline FORMATION & & & & & ار & & & & & & as & tric & ht & & Ioca & ities \\
\hline SPECIES & $\underset{\infty}{\infty}$ & 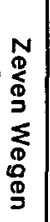 & 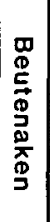 & $\leqq$ & $\begin{array}{l}\frac{r}{\bar{x}} \\
\frac{\vec{d}}{0} \\
-\end{array}$ & $\begin{array}{l}\frac{r}{\bar{x}} \\
\vec{\sigma} \\
N \\
N\end{array}$ & $\begin{array}{l}\bar{\sigma} \\
\overline{\bar{x}} \\
\bar{\sigma} \\
\omega\end{array}$ & 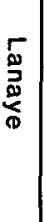 & 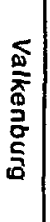 & 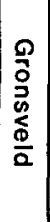 & 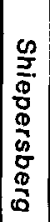 & 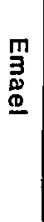 & $\begin{array}{l}z \\
\frac{z}{0} \\
\hat{x} \\
\mathbf{c}\end{array}$ & 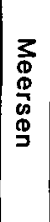 & $\begin{array}{l}\stackrel{9}{\mathbf{D}} \\
\stackrel{5}{\frac{5}{0}} \\
\stackrel{7}{3}\end{array}$ & 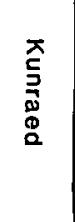 \\
\hline Saghalinites cala (Forbes, 1846) & & & & & & & & & & & & & & & & $\mathrm{x}$ \\
\hline $\begin{array}{l}\text { Pachydiscus gollevill ensis } \\
\text { (D'Orbigny, 1850) }\end{array}$ & & & & & & & & & & & & & & & & $x$ \\
\hline $\begin{array}{l}\text { Pachydiscus jacquoti } \\
\text { (Seunes, } 1890)\end{array}$ & & & & & & & & & & & & & & & & $x$ \\
\hline $\begin{array}{l}\text { Pachydiscus fresvillensis } \\
\text { (Seunes, 1890) }\end{array}$ & & & & & & & & & & & & & $?$ & $?$ & & $x$ \\
\hline $\begin{array}{l}\text { Hoplitoplacenticeras marroti } \\
\text { (Coquand, 1859) }\end{array}$ & $x$ & & & & & & & & & & & & & & & \\
\hline Hoplitoplacenticeras sp. & & $\mathrm{x}$ & & & & & & & & & & & & & & \\
\hline $\begin{array}{l}\text { Sphenodiscus binkhorsti } \\
\text { (Bohm, 1898) }\end{array}$ & & & & & & & & & & & & & & $\mathrm{X}$ & $\mathrm{x}$ & \\
\hline Baculites anceps Lamarck, 1822 & & & & & & & & & & & & & & & $\mathrm{x}$ & $\mathrm{x}$ \\
\hline Baculites vertebralis Lamarck, 1801 & & & & & & & & & $x$ & & & & $\mathrm{x}$ & & & $x$ \\
\hline Baculites carinatus Binkhorst, 1861 & & & & & & & & & & & & & $?$ & $?$ & & \\
\hline Baculites sp. 1 & & $\mathrm{x}$ & & & & & & & & & & & & & & \\
\hline Baculites sp. 2 & & $\mathrm{x}$ & & & & & & & & & & & & & & \\
\hline Baculites sp. 3 & & & & & & & & & $x$ & & & & & & & \\
\hline Eubaculites vagina (Forbes, 1846) & & & & & & & & & & & & & $?$ & $?$ & & \\
\hline 'Scaphites roemeri' Auctorum & & & & & & & & & & & & & & $\bar{x}$ & & $\bar{x}$ \\
\hline$\frac{\text { Hoploscaphites c. constrictus }}{(\mathrm{J}}$ & & & & $?$ & & & & & & & & & & $x$ & $x$ & $x$ \\
\hline $\begin{array}{l}\text { Hoploscaphites c. crassus } \\
\text { (Lopuski, 1911) }\end{array}$ & & & & & & & & & & & & & & $x$ & ? & \\
\hline $\begin{array}{l}\text { Acanthoscaphites trinodosus } \\
\text { (Kner, 1850) }\end{array}$ & & $x$ & & & & & & & & & & & & & & \\
\hline $\begin{array}{l}\text { Acanthoscaphites pungens } \\
\text { (Binkhorst, }\end{array}$ & & & & & & & & & & & & & & & $x$ & \\
\hline Acanthoscaphites verneuilianus & & & & & & & & & & & & & & & & $x$ \\
\hline Acanthoscaphites spp. & & & & & & & & & & & & & & & $\mathrm{x}$ & \\
\hline Diplomoceras cylindraceum Auctorum & & & & & & & & & & & & & $\mathrm{x}$ & $?$ & & $\mathrm{x}$ \\
\hline 'Glyptoxoceras' sp. & & & & & & & & & & & & & & & & $\mathrm{x}$ \\
\hline Nostoceras sp. & & & & & & & & & & & & & & $\mathrm{x}$ & & \\
\hline
\end{tabular}

Table 6. Ammonite records from the Maastricht area. 
state of chaos at present. The appearance of Placenticeras bidorsatum appears to be a good potential marker for the base of the stage, the species evolving paedomorphically from $P$. paraplanum of the Upper Santonian. Unfortunately the species is known from a handful of localities only (de Grossouvre 1894). The "delawarensis" Zone is generally barren, while the true identity of the rare French material and its relationship to the American species is unresolved. Ammonites are not uncommon in the vari, correctly marroti Zone, at some localities. There are, however, at least four Hoplitoplacenticeras species present in Aquitaine and the old records of vari are unreliable. The polyplocum Zone is well represented by new material from the environs of Royan (I thank Dr. P. Moreau for allowing me to study these specimens), and ammonites can still be collected on the coast to the south, at the top of Arnaud's P ${ }^{3}$.

Ammonites become rare in the tuffeau facies with Orbitoides that succeed $\mathrm{P}^{3}$. Arnaud's Assize $\mathrm{Q}$ is still within the Campanian, yielding typical polyplocum Zone forms at many localities. The highest ammonite fauna found in Aquitaine is that of the tuffeau facies around Maurens (Dordogne) and the Silex de Mussidan (Dordogne). Baculites are common, but are not Baculites anceps (Lamarck, 1799), a Maastrichtian species to which they were referred by de Grossouvre, while sphenodiscids present ( $S$. ubaghsi de Grossouvre, 1894 and $S$. rutoti de Grossouvre, 1894) represent a group that occurs in both Upper Campanian and Maastrichtian according to Zaborski (1983).

Unpublished observations by Dr. M. Bilotte and myself suggest that these spenodiscids may occur below the first appearance of Hoploscaphites constrictus (J. Sowerby, 1817) in the Petit Pyrénées and might thus be construed to be Upper Campanian. The $H$. constrictus include rather late forms of the species, while the sphenodiscids occur above a single Hoploscaphites compared to H. pumilis (Stephenson, 1941). In New Jersey this occurs with pachydiscids identified as Pachydiscus cf. neubergicus (Von Hauer, 1858), a species I will propose below as a possible Maastrichtian marker.

Definition of the base of the Campanian in ammonite terms presents considerable difficulties. The appearance of Placenticeras bidor- satum (Roemer, 1841) corresponds to the 'classic' definition, but this species is so rare in the Aquitaine Basin as to render it impractical. Alternative sections might be found in the Germanies, but, even here, there are few examples, while the species appears to be restricted to north-western Europe. More widely occurring are representatives of the Texanitinae, and the evolution of Submortoniceras from Texanites is probably the most satisfactory marker in this group. Submortoniceras is known from Spain, Zululand, Madagascar, Mexico, the Gulf and Pacific Coasts of the United States and British Columbia, but not from the type areas of France. As a third possible group, the Scaphitidae include an important Santonian-Campanian lineage in the form of the group of Scaphites hippocrepis (De Kay, 1827). This has been the subject of a masterly review by Cobban (1969). Specimens referred to as Scaphites aquisgranensis (Schlüter, 1872) by European authors that occur with Plancenticeras bidorsatum in Europe are regarded by Cobban as representatives of the latest of three distinct forms of $S$. hippocrepis (S. hippocrepis III), which occurs widely in the U.S. Western Interior, the Atlantic and Gulf Coast plains, the Aquitaine Basin, West Germany, Belgium and Holland.

\section{Maastrichtian}

The type section of the Maastrichtian Stage in St. Pietersberg near Maastricht in eastern Holland, where only the upper part of the stage is present, and even the uppermost Maastrichtian is absent. A type section has been designated at the ENCI quarry. The lower boundary of the Maastrichtian, where exposed in the Maastricht area, is a marked discontinuity surface. As a result, Surlyk (1975, 1982) and Schulz (1978) proposed a boundary stratotype at Kronsmoor in north Germany, corresponding, at that locality, to the base of the Belemnella lanceolata Zone, with the first Hoploscaphites constrictus appearing 3.5 to $5 \mathrm{~m}$ above the base.

Standard zonations of the Maastrichtian have not been widely accepted. One definition has been to consider the stage to correspond to the total range zone of Hoploscaphites constrictus; Wright (in Arkell et al. 1957) gave a zonation of: 
Sphenodiscus sp. (above)

Pachydiscus neubergicus (below)

for the "Cretaceous of Classic Areas of Western Europe." Given a Maastrichtian that lasted around 7 Ma (Odin 1983) and the presence of genera (Hoploscaphites, Baculites) that provide fine biozonations elsewhere in the world, the situation is an unsatisfactory one. So far as the area around Maastricht is concerned my observations are of a preliminary nature only; table 6 summarises the ammonite records gleaned from published literature and the old collections at Brussels and Maastricht.

Defining the base of the Maastrichtian by ammonites has several possible solutions. The Kronsmoor section in the White Chalk facies of north Germany has obvious attractions as a western European boundary stratotype, taking the base of the Belemnella lanceolata Zone as the base of the stage which can in turn be correlated with the first occurrence, a few metres higher, of Hoploscaphites constrictus as well as with echinoid and benthic foram zones. It must be remembered, however, that this Boreal sequence of faunas cannot easily be applied to the greater part of the world. Should we instead, at least consider a group that occurs in the European White Chalk region, in the north Tethys and indeed, in the southern hemisphere, that is to say the ammonite family Pachydiscidae? Specifically, should we take the first appearance of Pachydiscus neubergicus (von Hauer, 1858) as the ammonite indicator of the base of the Maastrichtian? The advantages of this solution are:

1. It occurs in the European White Chalk sequence (Denmark, N. Germany) and can be linked to the belemnite sequences there.

2. It occurs in the tectonically complex areas of Alpine Europe (the type locality, Neuberg, Styria, associated with the widespread Maastrichtian marker Eubaculites plus Diplomoceras cylindraceum (d'Orbigny, 1842) and Hoploscaphites tenuistriatus (Kner, 1848)).

3. It occurs in north Tethyan pelagic facies with good Inoceramus, micro- and nannofossil associations (Zumaya, N. Spain; Landes, France).

4. It occurs in eastern North America associated with widely recorded Nostoceras such as $N$. hyatti Stephenson, 1941.

5. It occurs in the Indo-Pacific region associ- ated with diverse ammonites and other groups (southern India, Zululand, South Africa).

6. In Zululand, South Africa it occurs with diagnostic elements of the New Zealand - W. Australia - Antarctica 'Upper Campanian' Gunnarites fauna.

As a boundary section the Zumaya sequence may prove a satisfactory one, given the extensive faunas now being studied by Drs. Ward and Wiedmann. It must be stressed, however, that $P$. neubergicus may have a long vertical range in the Maastrichtian, for it is a species that spans the Belemnella occidentalis / Belemnitella junior Zone boundary in Denmark (Birkelund 1979), and that mere occurrence is not an indication of the base of the stage.

\section{Conclusions}

In ammonite terms, the possibility that the bases of the Upper Cretaceous stages can be satisfactorily defined as follows is proposed for further study and discussion:

1. Cenomanian: appearance of either Hypoturrilites or Neostlingoceras lineage in the Tunisian sections.

2. Turonian: appearance of Pseudaspidoceras flexuosum in the west Texas - New Mexico area.

3. Coniacian: appearance of Forresteria (Harleites) petrocoriensis in N. German/Czech sequences.

4. Santonian: appearance of Texanites.

5. Campanian: appearance of Placenticeras bidorsatum in Europe or Submortoniceras elsewhere or on the basis of evolutionary changes within the Scaphites hippocrepis lineage.

6. Maastrichtian: appearance of Pachydiscus neubergicus.

Acknowledgements. I thank many colleagues in Museums throughout Europe who have helped me locate ammonites from the type areas of the Upper Cretaceous stages, notably A. W. F. Meijer (Maastricht), A. Dhondt (Brussels), J. Sornay and D. Pajaud (Paris), J. Louail (Rennes), G. Marie (Le Mans), A. Prieur and R. Busnardo (Lyons), J. Philip (Marseille), D. Phillips and M. K. Howarth (London). P. Juignet (Rouen) and A. Lebert (Mamers) have shown me countless ammonites from the type Cenomanian; F. Amédo (Le Havre) has provided lively comments on many aspects of Cretaceous stratigraphy, J. M. Hancock (London) much advice and assis- 
tance in both field and laboratory and C. W. Wright (Seaborough) much constructive criticism. The technical assistance of the staff of the Geological Collections, University Museum, Oxford, is gratefully acknowledged, as is the financial support of the British Association for the Advancement of Science, Royal Society and Natural Environment Research Council.

\section{Dansk sammendrag}

Brugen af ammonit »standard zonerne « $i$ øre kridt etagerne $i$ Vesturopa vurderes kritisk. Det foreslås at definere øvre kridts etager på grundlag af første optræden af følgende ammoniter: cenomanien: Hypoturrilites eller Neostlingoceras; turonien: Pseudaspidoceras flexuosum; Coniacien: Forresteria petrocoriensis; santonien: Texanites; campanien: Placenticeras bidorsatum eller Submortoniceras eller stadier af Scaphites hippocrepis udviklingslinien; maastrichtien: Pachydiscus neubergicus.

\section{References}

Alcaydé, G. (ed.). 1983: Colloque sur le Turonien. Mém. Mus. nat. Hist. Nat. Paris, C, 49, 241 pp.

Arkell, W. J., Kummel, B. \& Wright, C. W. 1957: Mesozoic Ammonoidea. In Moore, R. C. (ed.). Treatise on Invertebrate Paleontology, Part L, Mollusca 4, Cephalopoda Ammonoidea, L80-L465. Lawrence Geol. Soc. Amer. \& Univ. Kansas Press.

Bilotte, M., Calandra, F. \& Collignon, M. 1971: Stratigraphie du Crétacé Supérieur du synclinal de Rennes-les-Bains (Pyrénées Audoises). C.r. hebd. Séanc. Acad. Sci., Paris, (D), 273, 16-18.

Bilotte, M. \& Collignon, M. 1983: Biostratigraphie et Paléontologie des ammonites du Sénonien Inférieur de Rennesles-Bains-Sougraine (Aude) Zone sous-Pyrénéenne Oriental. Docum. Lab. géol. Lyon H. S. 6, 175-223.

Birkelund, T. 1979: The last Maastrichtian ammonites. Pp. 5157 In Cretaceous - Tertiary Boundary Events Symposium, 1. The Maastrichtian and Danian of Denmark. $210 \mathrm{pp}$. Copenhagen.

Blaskiewicz, A. 1980: Campanian and Maastrichtian ammonites of the Middle Vistula Valley, Poland: a stratigraphic-paleontologic study. Pr. Inst. geol. 92, 1-63.

Cobban, W. A. 1969: The late Cretaceous Ammonites Scaphites leei Reeside and Scaphites hippocrepis (De Kay) in the Western Interior of the United States. Prof. Pap. U.S. geol. Surv. 619, 1-27.

Collignon, M. 1939: Fossiles cénomaniens et turoniens du Menabe (Madagascar). Annls géol. Serv. Mines Madagascar, $10,59-105$.

Collignon, M. 1960: Corrélations Sommaires entre les dépôts du Crétacé Supérieur de Madagascar et ceux de l' Europe occidentale, en particulier de la France. C.r. congrés Sociétés Savantes-Dijon 1959: Colloque sur le Crétacé supérieur français, 41-52.

Collignon, M. 1966: Atlas des Fossiles caractéristiques de Madagascar (Ammonites). XIV, Santonien. X + 134 pp., pls. 455-513. Tananarive, Service Géologique.

Dubourdieu, G. 1953: Ammonites nouvelles des Monts du Mellègue. Bull. Serv. Carte géol. Algér., 1’ sér., Paléontologie, $16,76 \mathrm{pp}$.

Dubourdieu, G. 1956: Étude géologique de la région de l' Ouenza (confins Algéro-Tunisiennes). Bull. Serv. Carte géol. Algér., n.s., 10, 659 pp.
Grossouvre, A. de 1894: Recherches sur la craie supérieure, 2, Paléontologie. Les ammonites de la craie supérieure. Mém. Serv. Carte géol. dét. Fr., 264 pp. (misdated 1893).

Grossouvre, A. de 1901: Recherches sur la craie supérieure 1: stratigraphie générale. Mém. Serv. Carte géol. dét. Fr. vii $+1013 \mathrm{pp}$.

Guéranger, E. 1867: Album paléontologique du département de la Sarthe. 20 pp. Le Mans, Monnoyer.

Guillier, A. 1886: Géologie du départment de la Sarthe. xii + 430 pp. Le Mans, Monnoyer.

Hancock, J. M. 1960: Les ammonites du Cénomanien de la Sarthe. C.r. congrès Sociêtés Savantes-Dijon 1959: Colloque sur le crétacé supérieur français, 249-252. (misdated 1959).

Hancock, J. M. \& Kennedy, W. J. 1981: Upper Cretaceous ammonite stratigraphy: some current problems. In House, M. R. \& Senior, J. R. (eds.) The Ammonoidea. Spec. Vol. Syst. Ass. 18, 531-553.

Haug, E. 1908-1911: Traite de Géologie. Masson, Paris.

Hook, S. C. \& Cobban, W. A. 1981: Late Greenhorn (Mid Cretaceous) discontinuity surfaces, southwest New Mexico. Circ. Bur. Min. Technol. New Mex. 180, 5-21.

Jarvis, I., Gale, A. \& Clayton, C. 1982: Stratigraphy of the Craie de Villedieu Formation (Upper Cretaceous), western France: Key to the correlation of the Coniacian-Santonian in N. W. Europe. Newsl. Stratigr. 11, 64-82.

Juignet, P. 1974: La transgression crétacée sur la bordure orientale du Massif armoricain. Aptien, Albien, Cénomanien de Normandie et du Maine. Le stratotype du Cénomanien. Thése, Université Caen, $810 \mathrm{pp}$.

Juignet, P. 1977: Ammonite faunas from the Cenomanian around Le Mans (Sarthe, France). Spec. Pap. palaeont. Soc. Japan, 21, 143-150.

Juignet, P., Damotte, R., Fauconier, D., Kennedy, W. J., Magniez-Jannin, F., Monciardini, C. \& Odin, G. S. in press: La limite Albien-Cénomanien dans la Sarthe. Étude de trois sondages dans la région type du Cénomanien. Bull. Bur. Rech. géol. min. Paris.

Juignet, P. \& Kennedy, W. J, 1976: Faunes d'ammonites et biostratigraphie comparé du Cénomanien du nord-ouest de la France (Normandie) et du sud de l'Angleterre. Bull. trimestr. Soc. géol. Normandie amis Mus. Havre, 63, 1-193.

Juignet, P., Kennedy, W. J. \& Lebert, A. 1978: Le Cénomanien du Maine: formations sédimentaires et faunes d'ammonites du stratotype. Géol. Méditeranéenne 5, 87-100.

Juignet, P., Kennedy, W. J. \& Wright, C. W. 1973: La limite Cénomanien-Turonien dans la région du Mans (Sarthe): stratigraphie et paléontologie. Annls Paléont. (Invert.), 59, 209-242.

Kennedy, W. J. in press: Systematic palaeontology and stratigraphic distribution of the ammonite faunas of the French Coniacian. Spec. Pap. Palaeont.

Kennedy, W. J., Amedro, F., Badillet, G., Hancock, J. M. and Wright, C. W. 1984: Notes on late Cenomanian and Turonian ammonites from western France. Cret. Research, 5, $29-45$.

Kennedy, W. J. \& Juignet, P. 1973: Observations on the lithostratigraphy and ammonite succession across the Cenomanian - Turonian boundary in the environs of Le Mans (Sarthe, N. W. France) Newsl. Stratigr., 2, 189-202.

Kennedy, W. J. \& Juignet, P. 1983: A revision of the Ammonite Faunas of the Type Cenomanian. I. Introduction, Ancyloceratina. Cret. Research, 4, 3-83.

Kennedy, W. J. \& Juignet, P. in press: A revision of the ammonite faunas of the type Cenomanian. 2. The families Binneyitidae, Desmoceratidae, Engonoceratidae, Placenticeratidae, Hoplitidae, Schloenbachiidae, Lyelliceratidae and Forbesiceratidae. Cret. Research. 
Kennedy, W. J. \& Klinger, H. C. 1975: Cretaceous faunas from Zululand and Natal, South Africa. Introduction Stratigraphy. Bull. Br. Mus. nat. Hist. (Geol.) 25, 263-315.

Kennedy, W. J., Klinger, H. C. \& Summesberger, H. 1981: Cretaceous faunas from Zululand and Natal, South Africa. Additional observations on the ammonite subfamily Texanitinae Collingnon, 1948. Ann. S. Afr. Mus. 86, 115-155.

Kennedy, W. J. \& Wright, C. W. 1983: Ammonites polyopsis Dujardin, 1837 and the Cretaceous ammonite family Placenticeratidae Hyatt, 1900. Palaeontology, 26, 855-873.

Kennedy, W. J. Wright, C. W., \& Hancock, J. M. 1983: Ammonite zonation and correlation of the uppermost Cenomanian and Turonian of southern England and the type areas of Sarthe and Touraine in France. Mém. Mus. natn. Hist. nat. Paris, Ser. C, 49, 175-181.

Kennedy, W. J., Wright, C. W. \& Klinger, H. C. 1983: Cretaceous faunas from Zululand and Natal, South Africa. The ammonite subfamily Barroisiceratinae Basse, 1947. Ann. S. Afr. Mus. 90, 241-324.

Klinger, H. C. \& Kennedy, W. J. 1980: Cretaceous faunas from Zululand and Natal, South Africa. The ammonite subfamily Texanitinae Collignon, 1948. Ann. S. Afr. Mus. 80, 1-357.

Lewy, Z., Kennedy, W. J. and Chancellor, G. R. in press: Cooccurrence of Metoicoceras geslinianum (d'Orbigny) and Vascoceras cauvini Chudeau (Cretaceous Ammonoidea) in the Southern Negev (Israel) and its stratigraphic implications. Newsl. Stratigr.

Marks, P. 1967a: Rotalipora et Globotruncana dans la Craie de Théligny (Cénomanien, dépt. de la Sarthe). Proc. K. ned. Akad. Wet., Ser. B, 70, 264-275.

Marks, P. 1967b: Foraminifera from the Craie de Théligny (Cenomanian, dept. Sarthe, France). Ibid., 70, 425-442.

Odin, G. S. 1983: Numerical age of the Cretaceous stage boundaries. Pp. 145-147 In Abstracts, Cretaceous Stage Boundaries Symposium, Copenhagen, 1983. vii +210 pp. Copenhagen.

Orbigny, A. d'. 1840-1842: Paléontologie française: Terrains crétacés. 1. Céphalopodes. 1-120 (1840); 121-430 (1841); 431-662 (1842). Paris, Masson.

Orbigny, A. d'. 1842-1843: Paléontologie française; Terrains crétacés. 2, Gasteropodes, 1-224 (1842); 225-456 (1843). Paris, Masson.

Orbigny, A. d'. 1848-51: Paléontologie française: Terrains crétacés, 4, Brachiopodes. 1-32 (1847 (1848)); 33-104 (1848); 105-390 (1851) Paris, Masson.

Orbigny, A. d'. 1850; Prodrome de Paléontologie stratigraphique universelle des animaux mollusques et rayonnés. 2, 428 pp., Paris, Masson.

Orbigny, A. d'. 1852: Cours Elementaire de Paléontologie et de Géologie Stratigraphique. 2, 383-847. Paris, Masson.

Powell, J. D. 1963: Cenomanian-Turonian (Cretaceous) ammonites from Trans-Pecos Texas and north-eastern Chihuahua, Mexico. J. Paleont. 37, 309-322.

Robaszynski, F. (Coordinateur). 1982: Le Turonien de la région-type: Saumurois et Touraine. Stratigraphie, biozonations, sédimentologie. Bull. Cent. Expl. Prod. Elf-Aquitaine, 6, 119-225.

Robaszynski, F., Alcaydé, G,, Amédro, F., Badillet, G., Damotte, R., Foucher, J. C., Jardiné, S., Legoux, O., Manivit, H., Monciardini, E. \& Sornay, J. 1983: L'étage Turonien dans sa région type "de Saumur à Montrichard". biostratigraphie, sédimentologie, coupures. Mem. Mus. natn. Hist. nat. Paris, Ser. C, 49, 15-28.

Robaszynski, F. \& Amedro, F. (eds.), 1980: Synthèse biostratigraphique de l'Aptien au Santonien du Boulonnais à partir de sept groupes paléontologiques: Foraminifères, Nannoplancton, Dinoflagelles et macrofaunes. Révue Micropaleont., 22 (4), 195-321.
Salaj, J. 1973: Proposition pour des Néostratotypes du Crétacé supérieur (en vue de la zonational des regions de la Thetys). Livre Jubilaire M. Solignac. Annls Mines Géol., Tunis, 26, 219-222.

Salaj, J. 1974: Microbiostratigraphie du Crétacê superieur de la région de Pont du Fahs. Livret-guide des Excursions du VI Colloque Africain Micropaleontologique, 41-49. Tunis.

Salaj, J. \& Bellier, J. P. 1978: Une coupe de reference pour la zonation de l'Albien, du Cénomanien et du Turonien de Tunisie Septentrionale. Ann. Mus. Hist. Nat. Nice, 4, XXI, $1-9$.

Schlanger, S. O., Arthur, M. A., Jenkyns, H. C. \& Scholle, P. $A$. in press: The Cenomanian-Turonian anoxic event. 1. Stratigraphy and distribution of organic carbon-rich beds and the marine $\delta^{13} \mathrm{C}$ excusion. Jl. geol. Soc. Lond.

Schlüter, C. 1871-1876: Cephalopoden der oberen deutschen Kreide. Palaeontographica, 21, 1-24 (1871); 21, 25-120 (1872); 24, 1-144 (121-264) + x (1876).

Schulz, M. G. 1978: Zur Litho- und Biostratigraphie des Ober Campan - Untermaastricht von Lägerdorf und Kronsmoor (SW-Holstein) Newsl. Stratigr. 7, 73-89.

Séronie-Vivien, M. 1972: Contribution a l'étude du Sénonien en Aquitaine septentrionale. Les stratotypes: Coniacien Santonien, Campanien. 195 pp. Paris.

Surlyk, F. 1975: Die Brachiopoden der Hemmoorer Schreibkreide. Paläont. Ges. 45, Jahresversammlung in Hannover, $1 \mathrm{p}$.

Surlyk, F. 1982: Brachiopods from the Campanian-Maastrichtian boundary sequence, Kronsmoor (NW Germany). Geol. Jb. A61, 259-277.

Takayanagi, Y. \& Matsumoto, T. 1981: Recent advances in the Cretaceous biostratigraphy of Japan by coordinating megaand micro-fossils. Rec. Progr. Nat. Sci. Japan, 6, 125-137.

Thomel, G. 1973: A propos de la limite entre les étages Cénomanien et Turonien. C.r. hebd. Séanc. Acad. Sci., Paris, (D), 277, 761-764.

Wiedmann, J. 1979: Die Ammoniten der N. W. - deutschen, Regensburger und Ostalpinen Oberkreide im Vergleich mit den Oberkreide fauna des westlichen Mediterrangebiets. Aspekte der Kreide Europas. IUGS Series A, 6, 335-350.

Wright, C. W. \& Kennedy, W. J. 1981: The Ammonoidea of the Plenus Marls and the Middle Chalk. Palaeontogr. Soc. (Monogr.), $148 \mathrm{pp}$.

Wright, C. W., Kennedy, W. J. \& Hancock, J. M. in press: Stratigraphic Introduction In Wright, C. W. \& Kennedy, W. J. A Monograph of the Ammonoidea of the Lower Chalk. Palaeontogr. Soc. (Monogr.)

Young, K. 1963: Upper Cretaceous ammonites from the Gulf Coast of the United States. Univ. Tex. Bull. 6304, ix +373 pp.

Zaborski, P. M. P. 1983: Campanian and Maastrichtian sphenodiscid ammonites from southern Nigeria. Bull. $B r$. Mus. nat. Hist. (Geol.), 36, 303-332. 